\title{
Assessment of Land Cover changes on long-term treated industrial effluent irrigation using Remote sensing and GIS techniques
}

\section{B. R. Iniyalakshimi*}

Department of Soil Science and Agricultural chemistry, Tamil Nadu Agricultural Article Info

University, Coimbatore (Tamil Nadu), India

R. Shanmugasundaram

Department of Soils and Environment, AC and RI, Madurai (Tamil Nadu), India

S. Avudainayagam

Department of Environmental Sciences, Tamil Nadu Agricultural University, Coimbatore (Tamil Nadu), India

\section{R. Jagadeeswaran}

Department of Crop Management, AC and RI, Kudumiyanmalai (Tamil Nadu), India

\section{S. Paul Sebastian}

Department of Environmental Sciences, Tamil Nadu Agricultural University, Coimbatore (Tamil Nadu), India

\section{P. Thangavel}

Department of Environmental Sciences, Tamil Nadu Agricultural University, Coimbatore (Tamil Nadu), India

${ }^{*}$ Corresponding author. E-mail: iniya.agri@gmail.com

\begin{abstract}
A study was under taken to identify and map the changes in land use and land cover over a period of (1992 to 2017) 25 years in an area irrigating with treated industrial waste water using remote sensing and GIS technologies. Four LANDSAT TM and ETM+ images of 1992, 1999, 2006 and 2017 with a spatial resolution 30mx30m were used to determine the temporal land cover changes. Consequently, ground truth confirmation was done in the study area. Supervised classification was carried out in ArcGIS to identify the LULC classes. The study area was classified into four major classes; Water bodies, Settlements, Vegetation and Fallow lands. The study revealed that fallow lands was decreased by $99.8 \%$, vegetation was found to be increased by $90.2 \%$ and settlement area was found to increase by $65.7 \%$ over the period of 15 years. Livelihood increased with increased socio-economic status of the people.
\end{abstract}

Keywords: Treated effluent irrigation; Land Use Land Cover change; RS and GIS; Thematic mapping

\section{INTRODUCTION}

The availability of fresh water was reduced and waste water generation was increased over the years due to rapid industrialization(EYASSOCHAM, 2019). Wastewater from the industries after proper treatments will be a potential source of irrigation to meet out the demand (Ramos et al., 2019). The paper and pulp industry is one of the largest industries in India consuming large quantities of water. Nearly $75-95 \%$ of fresh water used in the paper and pulp mill and discharge huge volumes of wastewater in the environment and categorized as one of the $17^{\text {th }}$ most polluting industries in the country (Sharma, Garg, and Arora, 2014). Based on the technology adapted, $72-225 \mathrm{~m}^{3}$ wastewater is let out per ton of paper produced (Tripathi, et al., 2014). Utilization of this waste water as an irrigation source is an effective method as it is a water source and also as a source of supplementary nutrients (Rezende, De Matos, Silva, and Neves, 2010).

Treated pulp and paper mill industrial effluent is the source of irrigation in the study area where it leads to an opportunity for increasing the cultivation of lands with agricultural crops. Change detection involves the observation of changes in a state over a period of time (Singh, 1989). Land Use Land Cover (LUCU) changes respond to socio-economic, political, cultural, demographic and environmental conditions and forces which are largely characterized by high human populations (Masek, Lindsay and Goward, 2000).

Hence, change detection is a key processes to determine the changes in an environment over a period of time (Lambin, 2001). LULC change de- 
tection was a tedious and time-consuming process before the advent of technologies. However, it has now become relatively simple and accurate due to the use of remote sensing (Zafrilla, Martinez-Espinosa, Alonso, and Bonete, 2010) (Zafrilla et al.) and geographic information system (GIS) techniques (Mas, 1999).

LULC mapping through RS (Remote sensing) techniques is now the most common method of monitoring the degree and extent of LULC degradation and development in an environment at spatial-temporal scales (Forkuo and Frimpong, 2012). These can be used as a database for monitoring, management and to improve policy decisions on land use, water management, land degradation and improvement and resource utilization. The present study area comprising of 1800 acres of land which was mostly fallow were brought to cultivation after the availability of treated waste water from the paper industry. With this background knowledge an attempt was made to map the LULC and to study its changes from the base year 1992 using Remote sensing and GIS techniques.

\section{MATERIALS AND METHODS}

Methodology: The study area is in Karur District of Tamil Nadu is lying between $10^{\circ} 45^{\prime}$ and $11^{\circ} 45^{\prime}$ North latitude and $77^{\circ} 45^{\prime}$ and $78^{\circ} 07^{\prime}$ East longitude. The minimum and maximum temperature of the region ranges from $19.0^{\circ}$ to $37.0^{\circ} \mathrm{C}$. The annual rainfall is $615 \mathrm{~mm}$ mostly during North East Monsoon. Tamil Nadu Newsprint and Papers Limited (TNPL) is one of the leading agro (bagasse pith) based pulp and paper industry in India established by the Government of Tamil Nadu during 1985 for the manufacture of newsprint, printing and writing paper in Kagithapuram of Karur District. It has the production capacity of 880 tonnes per day and annual production capacity of 4 , 00,000 tonnes. On an average $40 \mathrm{~m}^{3}$ of water is being used to produce one metric tonne of paper and this water reappears as wastewater.

Effluent water from the industry is treated by "Activated Sludge Process" effluent treatment system and found to be conforming totally to the Pollution Control Board norms for irrigating the lands estimated using standard protocols. Around 1800 acres of arid land are irrigated with the treated effluent water under TEWLIS (TNPL Effluent Water Lift Irrigation Society) scheme covering five villages namely, Moolimangalam, Thathampalayam, Pandipalayam, Ponniagoundenpudur and Pazhamapuram (Fig. 1). These village farmers utilize the treated paper mill effluent water as source of irrigation since 1993. The majority of TEWLIS farmers are cultivating Coconut trees intercropped with fodder grass by following flood irrigation practices.

LULC change detection and mapping: Satellite data that comprised of four years multi- temporal cloud free Land remote-sensing satellite (LANDSAT) satellite TIFF (Tagged Image File Format) imageries of 1992, 1999, 2006 and 2017 with a spatial resolution of $30 \mathrm{~m}$ were acquired from the USGS (United States Geographical Survey) GLOVIS website and GLCF (Global Land Cover Facility) (Table 1). Ancillary data included the ground truth data for the LULC classes. The ground truth data was in the form of reference points collected using Geographical Positioning System (GPS) for the 2017 image analysis, used for image classification and overall accuracy assessment of the classification results (Fig. 2).

The satellite images were preprocessed in ArcGIS 10.1 for mosaicking and sub setting the images of the study area. A false colour composite (FCC) of the satellite images was generated by using the green, red, and near-infrared (NIR) band combination. In Landsat 5 and 7 imageries, the green, red, NIR, and short-wave infrared (SWIR) bands are denoted by bands $2,3,4$, and 5 , respectively, whereas in Landsat 8 imageries, the green, red, NIR, and SWIR bands are denoted by bands 3,4 , 5 , and 6 , respectively.

Spectral signatures were created according to the variations in the spectral reflectance of the FCC image. Furthermore, supervised classification was performed using the maximum likelihood classification approach (Cheruto, Kauti, Kisangau, and Kariuki, 2016). The classification accuracy was verified by through field studies and ground truth data comparison for the 2017 datasets. The changes in the LULC classes over the study period were estimated in terms of the area in acres by using zonal statistics in ArcGIS 10.1, which are based on the pixel count and spatial resolution.

\section{RESULTS AND DISCUSSION}

Characteristics of treated industrial effluent irrigation water: The treated paper mill effluent had a high salt (especially sodium and chloride) and bicarbonate content. The characteristics of the effluent were within the requirements of the Indian Central Pollution Control Board (CPCB) standards of industrial wastewater for inland surface irrigation (Table 3).

Mapping of Land Use Land Cover classes for the study area of the above years were made and studied for its changes in terms of area in acres and the results obtained are discussed here. The delineated classes were Waterbodies, Settlements, Vegetation and Fallow lands (Table 2).

Area of LULC classes of the years 1992, 1999, 2006 and 2017: Fallow lands occupied 90 per cent (1683 acres) of study area and 8.7 per cent by vegetation before the supplement of irrigation source (1992). After five years of availability of irrigation source, the area of vegetation was 75 per cent and area under fallow lands are 24 per 

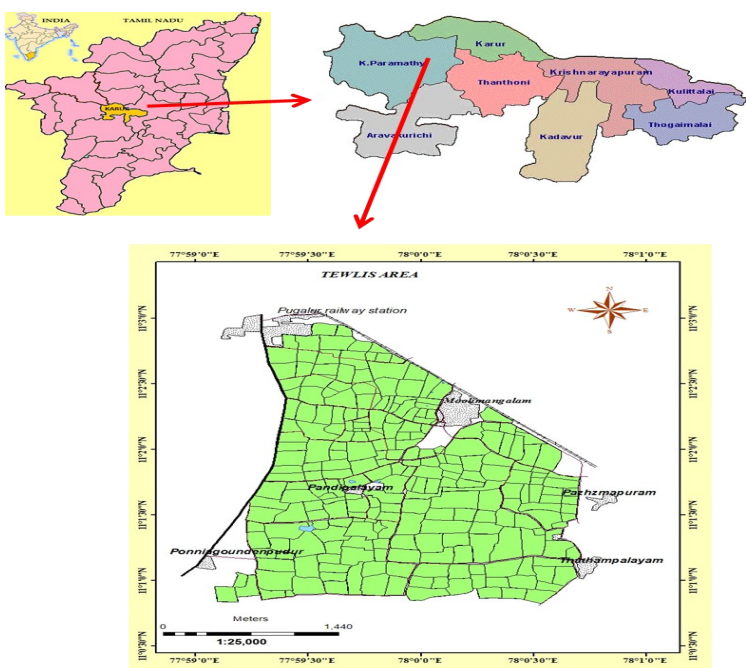

Fig. 1. Digitized study area and villages from Karur District of Tamil Nadu.

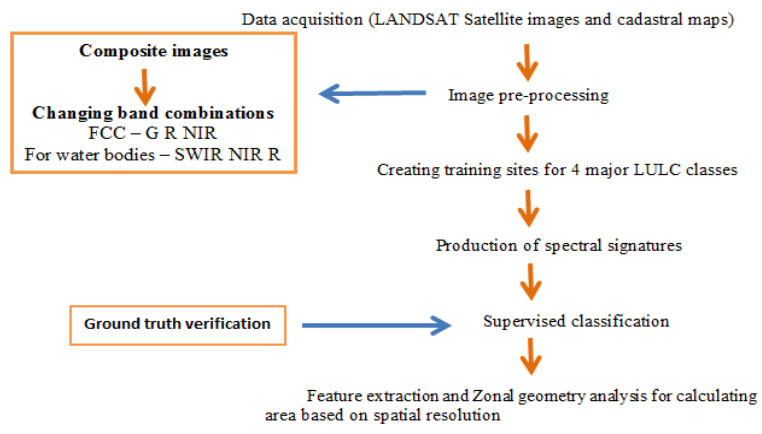

Fig. 2. Flowchart of methodology used for LULC mapping.

cent. During the year 2006, the area under settlement in the study area is found to be 1.39 per cent, 72 percentage of lands occupied by vegetation and 27 percentage of lands occupied by fallow lands. At present, 6.43 percentage of the study area is occupied by settlements and 92 percentage of area is occupied by vegetation. Area in acres under each LULC class of AOI is presented in the table 4. There was slight decline in the area of vegetation and a marginal increase in the area of fallow lands during the year 2006. This was due to the fact that the farmers were shifted from annual crops to perennial crops mainly coconut during that year. Hence more lands were under change in cropping pattern. At present, 97 per cent of area was under coconut plantation based on the survey.

\section{LULC change detection for the years 1992, 1999, 2006 and 2017}

Change detection between 1992 and 1999: One year before the availability of treated waste water as an irrigation source (1992), the area under vegetation is found to be very less and area under fallow was found to be very high with few areas under water bodies and settlements due to unavailability of any irrigation source. But after the
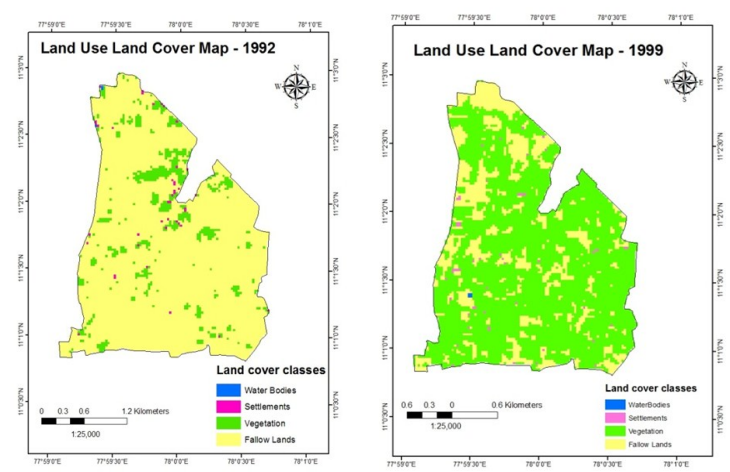

Fig. 3. Land Use Land Cover map of the study area of the year 1992 and 1999.
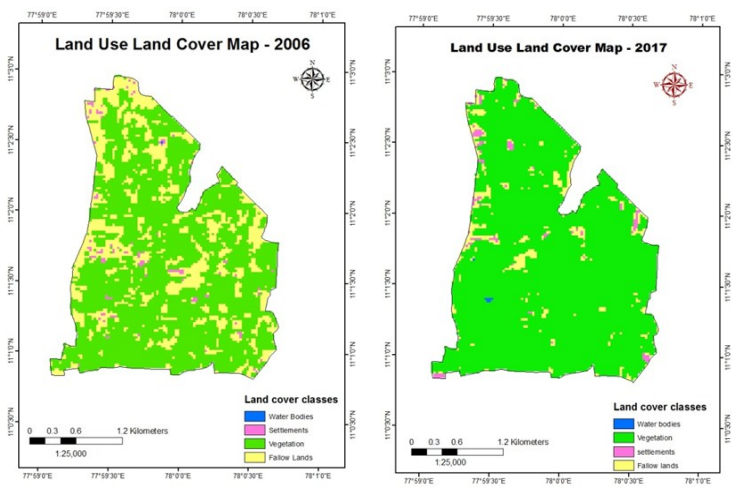

Fig. 4. Land Use Land Cover map of the study area of the year 2006 and 2017.

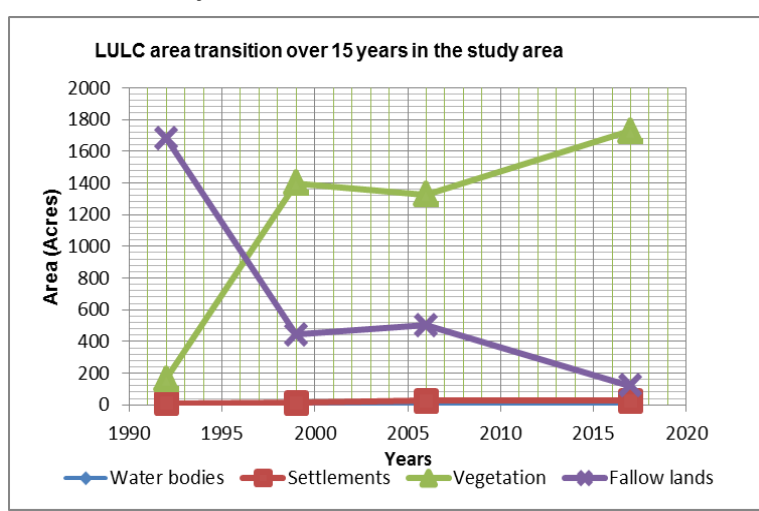

Fig. 5. Area transition for Land Use Land Cover classes of the study area from 1990s.

procurement of irrigation source for the 5 villages, within a period of six years interval, area under vegetation was increased from 8.72 per cent in 1992 to 75.32 per cent in 1999 with 88.4 percentage increase and fallow lands were decreased from 90.74 per cent in 1992 to 23.98 per cent in 1999 showing a 73.6 percentage decrease over a period of six years interval. LULC map of the years 1992 and 1999 is presented in Fig. 3.

Change detection between 1999 and 2006:

Area under vegetation was 4.9 per cent decreased from 75.3 per cent in 1999 to 71.59 per cent in 2006 whereas fallow lands were increased by 11.2 per cent from 23.98 per cent to 27.01 per cent over 
Table 1. Details of satellite imageries used in the study.

\begin{tabular}{lllllll}
\hline S.N. & Spacecraft Id & Sensor Id & Date of production & Entity ID & Source & Scale \\
\hline 1. & Landsat 5 & TM & 03.11 .1992 & p143r052_5dx19920311.TM & GLCF & $30 \mathrm{~m}$ \\
& & & -GLS1990 & LE71430521999258EDC00 & USGS & $30 \mathrm{~m}$ \\
2. & Landsat 7 & ETM+ & 15.09 .1999 & p143/r052/ & GLCF & $30 \mathrm{~m}$ \\
3. & Landsat 7 & ETM+ & 22.05 .2006 & L71143052_05220060121.E & & \\
& & & & TM-GLS2005 & & \\
& & & & LC81430522017107LGN00 & USGS & $30 \mathrm{~m}$ \\
\hline
\end{tabular}

* ETM+ - Enhanced Thermatic Mapper Plus

Table 2. Land class and description for supervised classification.

\begin{tabular}{|c|c|c|}
\hline S.N. & LULC Class & Description \\
\hline 1 & Water bodies & $\begin{array}{l}\text { This class of land cover describes the areas covered with water either along the river } \\
\text { bed or man-made earth dams, filled sand dams and ponds. }\end{array}$ \\
\hline 2 & Settlements & $\begin{array}{l}\text { This class describes the land covered with buildings in the rural and urban. It includes } \\
\text { commercial, residential, industrial and transportation infrastructures. }\end{array}$ \\
\hline 3 & Vegetation & This class of land cover defines all types of vegetation cover. \\
\hline 4 & Bare-land & $\begin{array}{l}\text { This describes the land left without vegetation cover. This result from abandoned crop } \\
\text { land, eroded land due to land degradation and weathered road surface. }\end{array}$ \\
\hline
\end{tabular}

Table 3. Characteristics of the treated effluent water used for irrigation.

\begin{tabular}{|c|c|c|c|c|}
\hline \multicolumn{5}{|l|}{ Parameters } \\
\hline \multicolumn{5}{|c|}{$\begin{array}{l}\text { Total Dissolved Solids }\left(\mathrm{mg} \mathrm{L}^{-1}\right) \\
\text { Total Suspended Solids }\left(\mathrm{mg} \mathrm{L}^{-1}\right) \\
\mathrm{pH} \\
\text { Electrical Conductivity }\left(\mathrm{dS} \mathrm{m}^{-1}\right) \\
\text { Biochemical Oxygen Demand }\left(\mathrm{mg} \mathrm{L}^{-1}\right) \\
\text { Chemical Oxygen Demand }\left(\mathrm{mg} \mathrm{L}^{-1}\right) \\
\text { Organic Carbon }(\%) \\
\text { Total Nitrogen }\left(\mathrm{mg} \mathrm{L}^{-1}\right) \\
\text { Total Phosphorus }\left(\mathrm{mg} \mathrm{L}^{-1}\right) \\
\text { Total Potassium }\left(\mathrm{mg} \mathrm{L}^{-1}\right) \\
\text { Calcium }\left(\mathrm{mg} \mathrm{L}^{-1}\right) \\
\text { Magnesium }\left(\mathrm{mg} \mathrm{L}^{-1}\right) \\
\text { Sodium }\left(\mathrm{mg} \mathrm{L}^{-1}\right) \\
\text { Chloride }\left(\mathrm{mg} \mathrm{L}^{-1}\right) \\
\text { Sulphate }\left(\mathrm{mg} \mathrm{L}^{-1}\right) \\
\text { Carbonate }\left(\mathrm{mg} \mathrm{L}^{-1}\right) \\
\text { Bicarbonate }\left(\mathrm{mg} \mathrm{L}^{-1}\right)\end{array}$} \\
\hline \multirow{2}{*}{ Classes } & & & & \\
\hline & 1992 & 1999 & 2006 & 2017 \\
\hline $\begin{array}{l}\text { Waterbodies } \\
\text { Settlements } \\
\text { Vegetation } \\
\text { Fallow lands }\end{array}$ & $\begin{array}{c}0.67 \\
9.34 \\
162 \\
1683 \\
\end{array}$ & $\begin{array}{c}0.89 \\
12.0 \\
1397 \\
445 \\
\end{array}$ & $\begin{array}{c}0.22 \\
25.8 \\
1328 \\
501 \\
\end{array}$ & $\begin{array}{c}1.58 \\
27 \\
1728 \\
121 \\
\end{array}$ \\
\hline
\end{tabular}

six years interval between 1999 and 2006 in the study area. The area under vegetation decreased and area under fallow lands were increased slightly is in the study area mainly due to shift in agricultural cropping pattern from annuals to perennials mainly coconut plantation during the study period. The above information on cropping pattern was obtained from survey made in the study area with the farmers.

Change detection between 2006 and 2017: A comparison was made over the LULC changes over a period of 10 years interval in the study area between 2006 and 2017. The study revealed that

\begin{tabular}{ll} 
Values & CPC \\
& $\mathbf{2 0 1 9}$ \\
\hline 1860 & 2100 \\
100 & 200 \\
8.01 & $5.5-9$ \\
3.57 & - \\
31.4 & 100 \\
251 & - \\
0.56 & - \\
252 & - \\
213 & - \\
390 & - \\
228 & - \\
28.8 & - \\
541 & - \\
602 & - \\
90.6 & - \\
36.0 & - \\
292 & - \\
\hline
\end{tabular}

CPCB Standards of Irrigation Water, 19 (Board, 2019)

$5.5-9$

100

there was 17 per cent increase in vegetation from 71.6 per cent to 92 per cent and fallow lands were drastically declined with 20.6 per cent over this 10 years interval from 27.01 per cent to 6.43 per cent. There was a change in area under settlement with 0.06 per cent increase over this period from 1.39 per cent in 2006 to 1.45 per cent in 2017. And there was 0.07 per cent increase in area under water bodies over the 10 years interval. LULC map of the years 2006 and 2017 is presented in Fig. 4.

Overall these years, shift in settlements have been recorded. Survey made in the study area states that many temporary settlements have been made during the year 1992 to 1999 for construction of effluent water lift irrigation system. Settlements were markedly increased during 2006 compared to 1996 due to development of social structures in the study area including proper roadways, schools, library, cultural centre, small indus- 
tries, etc. while the settlement area was declined in 2017 due to the coconut farms which hides or submerges the settlements in the study area.

Land use and land cover analysis: The results of the study revealed that over the period of 15 years from 1992 to 2017 , the area under vegetation and settlements were drastically increased to 90.2 and 65.7 percent respectively. While the area under fallow lands was drastically decreased to 99.8 per cent from 1992 to 2017 . There were no significant changes under water bodies class. The changes in LULC classes over a period of time were interpreted in the Figure 5. This shows that on the availability of irrigation source, the area under vegetation and settlements was increased leading to the development of socio-economic status and livelihood in the study area. The fallow lands before 15 years in the study area are under crop cultivation at present. Along with these developments, there is an increase towards the construction of new pavements, roads and other structures in the areas. LULC changes are complex and at the same time interrelated such that the expansion of one LULC type occurs at the expense of other LULC classes (Cheruto et al., 2016).

\section{Conclusion}

The outcome shows that, both increase and decrease of the different LULC classes from 1992 through to 2017. A significant change from some classes to others was observed. Landsat satellite images of 1992, 1999, 2006 and 2017 were used for the LULC mapping showed that major changes in land use is vegetation. Area under vegetation was increased over the period of 25 years by converting the fallow lands economically. The main factor influenced is the irrigation source from the industry where there was no enough resource before the establishment of effluent water irrigation system. Continuous LULC mapping should be carried out in order to quantify and characterize LULC changes. This will be useful monitor trends and empower resource administrators for natural resource management.

\section{REFERENCES}

1. Board, C. P. C. (2019). General standards for discharge of environmental pollutants part-a : effluents schedule - VI (Vol. Rule 3A, The Environment (Protection) Rules, 1986, pp. 545-548). New Delhi.

2. Cheruto, M. C., Kauti, M. K., Kisangau, P. D., and Kariuki, P. C. (2016). Assessment of land use and land cover change using GIS and remote sensing techniques: a case study of Makueni County, Kenya.

3. EY-ASSOCHAM. (2019). Effective water management: integrating innovation and technology (pp. 1222). New Delhi

4. Forkuo, E. K., and Frimpong, A. (2012). Analysis of forest cover change detection.

5. Lambin, E. F. (2001). Global land-use and land-cover change: what have we learned so far? Global Change News, 46, 27-30.

6. Mas, J.-F. (1999). Monitoring land-cover changes: a comparison of change detection techniques. International Journal of Remote Sensing, 20(1): 139-152.

7. Masek, J., Lindsay, F., and Goward, S. (2000). Dynamics of urban growth in the Washington DC metropolitan area, 1973-1996, from Landsat observations. International Journal of Remote Sensing, 21(18): 3473-3486.

8. Ramos, A. V., Gonzalez, E. N. A., Echeverri, G. T., Moreno, L. S., Jiménez, L. D., and Hernández, S. C. (2019). Potential Uses of Treated Municipal Wastewater in a Semiarid Region of Mexico. Sustainability, 11(8): 1-24.

9. Rezende, A., De Matos, A., Silva, C., and Neves, J. (2010). Irrigation of eucalyptus plantation using treated bleached kraft pulp mill effluent. Water Science and Technology, 62(9): 2150-2156.

10.Sharma, V., Garg, U. K., and Arora, D. (2014). Impact of pulp and paper mill effluent on physicochemical properties of soil. Arch Appl Sci Res, 6(2): 12-17.

11.Singh, A. (1989). Review article digital change detection techniques using remotely-sensed data. International Journal of Remote Sensing, 10(6): 989-1003.

12.Tripathi, B. M., Kumari, P., Weber, K. P., Saxena, A. K., Arora, D. K., and Kaushik, R. (2014). Influence of long term irrigation with pulp and paper mill effluent on the bacterial community structure and catabolic function in soil. Indian journal of microbiology, 54(1): 65-73.

13.Zafrilla, B., Martinez-Espinosa, R. M., Alonso, M. A., and Bonete, M. J. (2010). Biodiversity of Archaea and floral of two inland saltern ecosystems in the Alto Vinalopo Valley, Spain. Saline Systems, 6, 10. doi: 10.1186/1746-1448-6-10 